\title{
Allelophatic Effects of Gravellia Robusta, Eucalyptus Camaldulensis and Casuarina Equisetifolia on Germination and Root Length of Maize and Wheat
}

\author{
Andualem Ayalew ${ }^{*}$, Zebene Asfaw ${ }^{2}$ \\ ${ }^{1}$ Sirinka Agricultural research center \\ ${ }^{2}$ Hawassa University Wondo Genet College of Forestry and Natural resource \\ *Corresponding Authors: Andualem Ayalew, Sirinka Agricultural research center
}

\begin{abstract}
Gravellia robusta, Eucalyptus camaldulensis and Casuarina equisetifolia are the wide spread exotic species in Eastern Amhara. Allelopathy have either stimulatory or inhibitory effect on the germination percent and the radicle length of the crop, by the release of chemicals from plant parts in both natural and agricultural systems. The experiment was conducted in sirinka agricultural research center under the laboratory with an aim to identify inhibitory or stimulatory effect using bark and leaf leachates of selected exotic species on the germination and radicle length of test crops. Aqueous bark and leaf extracts were prepared by soaking $25 \mathrm{gm}$ powder for each selected species in $500 \mathrm{ml}$ distilled water for $48 \mathrm{hrs}$ and used the extract for the study. The effect of the leachates was tested by placing 100 seeds of maize and wheat separately in three replicate using complete randomized design (CRD). The data were using SAS software version 9.0.Leaf leachate of Eucalyptus camaldulensis showed inhibitory effect.While, Gravellia robusta and Casuarina equisetifolia showed stimulatory effect for on the germination and radicle growth of tested crops.Removing excess Eucalyptus camaldulensis leaf from the crop land should be done to reduce the alleophatic effect \& to enhance production of crops.
\end{abstract}

Key words: Allelopathy, ANOVA, Leachate. Inhibitory, Germination percent, Radicle growth

\section{INTRODUCTION}

The alarming rate of human population in Ethiopia exerts huge pressure for the decline of forest for fuel, timber and fodder and on agricultural land for food grains, thus to meet these demands agroforestry had been introduced (Tim,2007). Due to the nature of Agroforestry, crops productivity depends on the growth resources (sunlight, soil moisture, nutrients) and allelopathic interactions. Therefore, it is essential that the Eucalyptus species and allelopathic tree species compatibility with crops should be determined before planting in the agroforestry systems (Carolina et al., 2018; Hozayn et al., 2015; Sirawdink et al., 2011; Yakubu et al., 2018).

Allelophatic interactions are an important factor in determining species distribution and abundance within plant communities (Kristina et al., 2006). Eucalyptus species have proven with their allopathic. It exerts allopathic effects through auto toxicity, its leaf, stem\& root extracts /leachates reduce seed germination \& seedling growth of test crops like Vigna unguiculata, Hibiscus esculentus and Lycopersicon esculentum, Mungu bean except Zea mays (Abugre \& Apetorgbor, 2011; Aminul et al.,2019). Tilashwork, (2009) also confirmed that Eucalyptus showed negative effect for the sustainable cropping, soil and water conservation system. Alebachew et al, 2015; Getachew, 2016) found that the cultivation of Eucalyptus on neighboring food crops is not recommended because of their adverse effects (competition of moisture, shade effect on crop productivity in Amhara and Benishagul Gumuz regions, Ethiopia respectively. The allelophatic effect exerted by the leaf leachate of Eucalyptus has also retarding effect on the germination and growth of vegetables like Tomato (Sirawdink et al., 2011).While Carolina et al.,(2018) performed a research on Eucalyptus globulus Leaves Incorporated as Green Manure to Weed Control in Maize and found that for incorporation of E. globulus residues to soil could be a feasible practice to reduce the reliance on synthetic herbicides in maize-based cropping systems. Similar species of Gravelia known as Grevillea banksii allelophatic has positive effect on the germination of bean and maize seeds as well as the seedling length 
development of all crop species but inhibit rice seeds germination(Martial et al., 2020). Germination, root length and dry matter production of Sorghum, Cow pea and Sunflower is affected due to alleophatic effects of phenolic, trepenodes, and organic cyamide present at leaf leachate of Casurina equstifolia (Raveendra et al., 2002). The allelophatic of Casurina equstifolia on the contrary has a positive effect using spraying the leaf extract to reduce weed biomass and increase the wheat biomass on the farmers field (Hozayn et al. 2015). Carolina et al.,(2013) reported that, Eucalyptus globulus leaves also can be used as green manure for weed control in Maize based cropping system.

It was first widely studied in forestry system as allelopathy can affect many aspects of plant ecology including occurrence, growth, and plant succession, the structure of plant community, dominance, diversity\& plant productivity (Marianne et al. 2000). There allelophatic effect of tree species and their effect on different agricultural crops show either inhibitory or stimulatory effect. Therefore, a research on allelophatic effect may help us to develop sustainable measures to integrate tree with crops, to diversify crop production and diversity of plant species and to maintain the ecology.

\section{Materials ANd Methods}

\subsection{Description of the Study Area}

The study was carried out in Sirinka Agricultural research center on station with an altitude of $1850 \mathrm{~m}$ a.s.l and at $11^{\circ} 45^{\prime} 00^{\prime} ' \mathrm{~N}$ latitude and $39^{\circ} 36^{\prime} 36^{\prime}$ 'E longitude. The mean total annual rainfall (which mainly falls in the cropping season) is $945 \mathrm{~mm}$. The rainfall pattern of the areas is bimodal and its distribution is erratic; the effective rainy period extends from June to September. Mean annual average temperatures are 19.5(Amare, 2015).

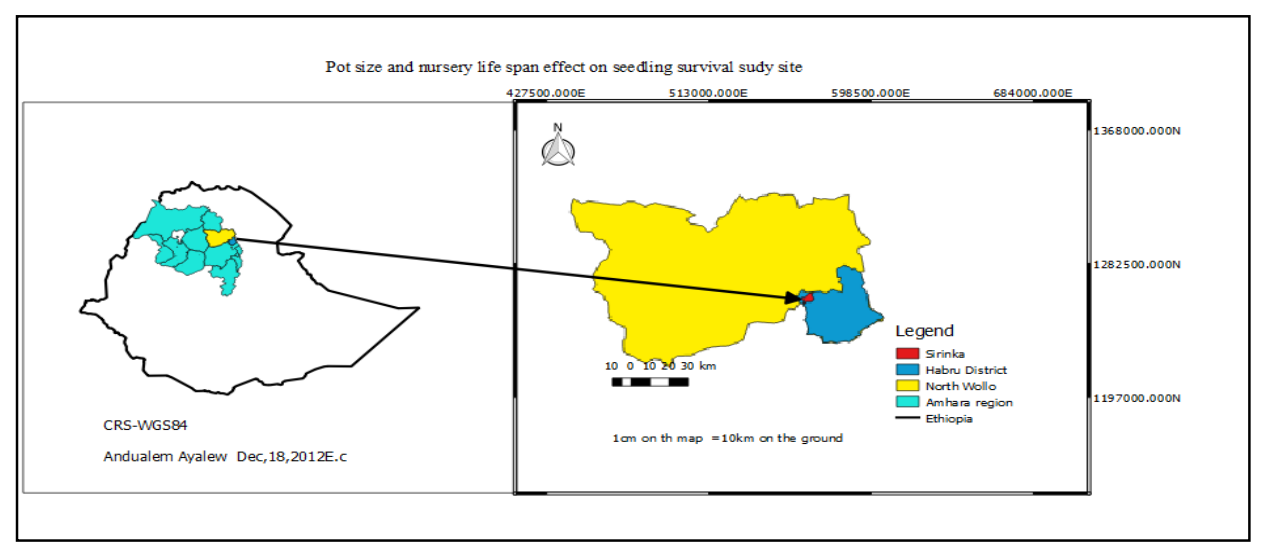

Figure1. Map of the study area

\subsection{Data Collection and Analysis}

The experiment were conducted in Sirinka agricultural research center with the collection of bark and leaf leachate of the selected tree species and control (with water) effect on wheat and maize in the laboratory. Bark and leaf was dried at room temperature and cut in $0.5-1 \mathrm{~cm}$ pieces. Bark and Leaf was pounded using electrical stainless material. Aqueous bark and leaf extracts were prepared by soaking $25 \mathrm{gm}$ powder for each selected species in $500 \mathrm{ml}$ distilled water (Sazada et al., 2009). Each container was soaked separately for 48 hours at room temperature and the extract were filtrated using Buchner funnel containing Whatman No. 1 filter paper and used for the study. Seeds of wheat and maize (100 seeds each) were put on Glass Fiber Filter Paper placed in a glass Petri-dish (GPD), $12 \mathrm{~cm}$ internal diameter. The experiment was conducted with three replication and four treatments using complete randomized design (CRD).The seeds were examined for germination at three days after initial germination. Moisture in petridish was maintained by adding $5 \mathrm{ml}$ aqueous extract to the germination of the tested crops.

Seeds were considered germinated when the radical growth is greater than or equal to $2 \mathrm{~mm}$. Germination percent was calculated by dividing number of seed germinated over the number of seed sown.

The data on the radicle growth was recorded at 7 days after sowing and subjected to statistical analysis using ANOVA. The statistical difference was detected using Dunken Multiple Range Test 
(DMRT) to compare the allopathic effects between treatments. The general impact of allelophatic on agricultural crops was assessed in the laboratory. The allelophatic effect of the selected tree species are investigated by taking bark and leaf leachate in the laboratory in order to see inhibitory or stimulatory effect on crops.

\section{RESUlT AND DisCUSSION}

In the present study, the bark leachate of Eucalyptus camaldulensis showed significantly stimulatory effect at $\mathrm{P}<0.0001$ on the germination of wheat, while significantly inhibitory effect at $\mathrm{P}<0.001$ on radicle growth of wheat. However, the leaf leachate of Eucalyptus camaldulensis showed significantly inhibitory effect at $\mathrm{P}<0.001$ on the germination and radicle growth of wheat. Gravellia robusta and Casuarina equisetifolia (Bark and leaf leachate) showed significantly stimulatory effect at $\mathrm{P}<0.0001$, and $\mathrm{P}<0.001$ on the germination and radicle growth of Wheat respectively (Table 1 and Table 2). Similarly the study reported by(Awadallah \& Eman, 2017) confirmed that, leaf leachate of Eucalyptus camaldulensis has allelopathic effects on seed germination and seedling growth of wheat (Triticum vulgare L.).M. G et al.,(2010) conducted the research on the allelophatic effect of Eucalyptus on the Mung bean and confirmed the leaf leachate of Eucalyptus camaldulensis leaves are not much more harmful for Mung bean growth. Thus, allelopathy could play an important role in weed management for farmers. The present study is in line with (Hozayn et al., 2015). On the contrary, the study is not inconsistent with the allelophatic effect of Casuarina equisetifolia on the germination and radicle growth of Wheat (Talaat et al.,2019).

Kugedera, \& Kokerai,(2019) reported similarly the allelochemicals released by Casuarina equisetifolia; it reduces growth and yield of Sorghum, sunflower and Cow pea. Raveendra et al.,(2002) reported similarly as wheat germination and root length affected due to the extract of leachate of Casuarina equisetifolia.

The present findings corroborate the earlier report by Sazada et al.,(2009) who found that, the inhibitory effect of leaf extracts of Prosopsis Juliflora leaf on the seed germination and radicle length of wheat was proportional to the concentration of the extract

Table1. Allelophatic effect of selected tree species on germination percent of wheat

\begin{tabular}{|l|l|l|l|l|}
\hline \multirow{2}{*}{ Tree species } & \multicolumn{2}{|l|}{ Bark leachate in percent } & \multicolumn{2}{l|}{ Leaf leachate in percent } \\
\cline { 2 - 5 } & Germination & effect level & Germination & Effect level \\
\hline Eucalyptus camaldulensis & 73.2 & +1.4 & 62.6 & -9.22 \\
\hline Gravellia robusta & 83.72 & +11.9 & 79.52 & +7.7 \\
\hline Casuarina equisetifolia & 77.3 & +5.5 & 74.7 & +2.88 \\
\hline Control & 71.82 & & 71.82 & \\
\hline R-square & 0.99 & & 0.99 & \\
\hline DMRT (5\%) & $<0.0001(\mathrm{NS})$ & & $<0.001$ & \\
\hline
\end{tabular}

Values in plus and minus sign under the effect level indicate the reduction/increment percentage in germination and radicle growth as compared to control.

Table2. Allelophatic effect of selected tree species on mean radicle growth of wheat

\begin{tabular}{|l|l|l|l|l|l|}
\hline \multirow{2}{*}{ Tree species } & \multicolumn{3}{|l|}{ Bark leachate in percent } & \multicolumn{2}{l|}{ Leaf leachate in percent } \\
\cline { 2 - 6 } & Radicle growth & effect level & & Radicle growth & Effect level \\
\hline Eucalyptus camaldulensis & 4.48 & -0.41 & & 3.4 & -1.49 \\
\hline Gravellia robusta & 5.17 & +0.28 & & 5.44 & +0.55 \\
\hline Casuarina equisetifolia & 6.2 & +1.31 & 5.11 & +0.22 \\
\hline Control & 4.89 & & 4.89 & \\
\hline R-square & 0.99 & & 0.97 & \\
\hline DMRT (5\%) & $<0.001$ & & $<0.001$ & \\
\hline
\end{tabular}

Values in plus and minus sign under the effect level indicate the reduction/increment percentage in germination and radicle growth as compared to control.CV\% is calculated by dividing standard deviation to mean.

In the present study, the bark leachate of Eucalyptus camaldulensis showed stimulatory effect on the germination of Maize, while the bark has inhibitory effect on radicle growth of Maize. However, the 
leaf leachate of Eucalyptus camaldulensis showed inhibitory effect on the germination and radicle growth of Maize. Gravellia robusta and Casuarina equisetifolia (Bark and leaf leachate) showed stimulatory effect on the germination and radicle growth of Maize (Table 3 and Table 4). Based on the allopathic effects of Eucalyptus species exerts through auto toxicity, its leaf, stem\& root extracts /leachates enhance seed germination \& seedling growth of Zea mays, (Abugre \& Apetorgbor, 2011; Aminul et al.,2019).While Awadallah et al.,(2017); Muhammad et al.,(2007) studied the effect of aqueous extracts of Eucalyptus camaldulensis L. on germination and growth of maize(Zea mays L.) and found out that seed germination $(\%)$ and radicle growth of Maize is reduced as a result of extract application of Eucalyptus species and have proven with their allopathic. On the contrary, the study is not inconsistent with the allelophatic effect of Casuarina equisetifolia on the germination and radicle growth of Maize (Talaat et al.,2019).

Yakubu et al.,(2018) reviewed in as many researchers found that allelochemicals have detrimental effects on the successive crops production which causes ecological and economic threat such as decline in total crop yield. Other Studies show that the actual release of the allelo-chemicals is difficult. This is due to many factors interact with allelo-chemicals in soil can cause inhibitory effects even though the concentrations of individual compounds are below their inhibitory levels(Marianne et al. 2000).The present study coincides with the study reported by C S, et al,(2000) which confirmed that, leaf leachate has showed more allelophatic effect than Bark. Furthermore, this finding which was done in the laboratory has similar implication to the field work reported by Alebachew et al, (2015); Getachew, (2016) found that the cultivation of Eucalyptus on neighboring food crops is not recommended because of their allelophatic effect on Agricultural crops in Amhara and Benishagul Gumuz regions, Ethiopia respectively.

Table3. Allelophatic effect of selected tree species on the germination percent of Maize

\begin{tabular}{|l|l|l|l|l|}
\hline \multirow{2}{*}{ Tree species } & \multicolumn{3}{|l|}{ Bark leachate in percent } & \multicolumn{2}{l|}{ Leaf leachate in percent } \\
\cline { 2 - 5 } Eucalyptus camaldulensis & Germination & effect level & Germination & Effect level \\
\hline Gravellia robusta & 73.22 & +1.4 & 62.68 & -9.12 \\
\hline Casuarina equisetifolia & 83.75 & +11.93 & 79.52 & +7.72 \\
\hline Control & 77.3 & +5.48 & 74.7 & +2.9 \\
\hline R-square & 71.82 & & 71.8 & \\
\hline DMRT (5\%) & 0.99 & & 0.99 & \\
\hline
\end{tabular}

Values in plus and minus sign under the effect level indicate the reduction/increment percentage in germination and radicle growth as compared to control.

Table4. Allelophatic effect of selected tree species on mean radicle growth of Maize

\begin{tabular}{|l|l|l|l|l|}
\hline \multirow{2}{*}{ Tree species } & \multicolumn{3}{|l|}{ Bark leachate in percent } & \multicolumn{2}{l|}{ Leaf leachate in percent } & \multicolumn{2}{l|}{ Effect level } \\
\cline { 2 - 5 } & Radiclegrowth(cm) & effect level & Radiclegrowth(cm) & -1.59 \\
\hline $\begin{array}{l}\text { Eucalyptus } \\
\text { camaldulensis }\end{array}$ & 4.5 & -0.39 & 3.3 & +0.56 \\
\hline Gravellia robusta & 5.2 & +0.31 & 5.45 & +0.21 \\
\hline Casuarina equisetifolia & 6.17 & +1.28 & 5.1 & \\
\hline Control & 4.89 & & 4.89 & \\
\hline R-square & 0.97 & & 0.99 & $<0.0001$ \\
\hline DMRT (5\%) & $<0.0001$ & & & \\
\hline
\end{tabular}

Values in plus and minus sign under the effect level indicate the reduction/increment percentage in germination and radicle growth as compared to control.

\section{CONCLuSion}

Based on the result, Eucalyptus camaldulensis showed inhibitory effect on the germination and radicle growth of wheat and Maize. Gravellia robusta and Casuarina equisetifolia have stimulatory effect on the germination and radicle growth of Wheat and Maize. This implies growing tested crops far distance from Eucalyptus camaldulensis and in close distance with Gravellia robusta and Casuarina equisetifolia is possible to remove the inhibitory and stimulatory effect of allephatic of the species respectively. Removing excess leaf litters from the crop growing areas should be done to reduce the alleophatic effect and to increase the germination, and the growth of the crops grown in the farmlands. 
It is advisable that growing of tested crops far away from the Eucalyptus plantation is helpful to reduce the allelo-chemical effect and increase the yields of the crops and also to separate the tested crops from Eucalyptus root using isolation trench.

\section{ACKNOWLEDGEMENT}

This work has been in its present shape with considerable professional and material inputs from various sources. Therefore, I deeply wish to extend thanks to Sirinka Agricultural Research Center that made this work possible. The views expressed in this paper cannot be taken to reflect the official opinions of this organization.

\section{REFERENCES}

[1] Abugre, S., \& Apetorgbor. (2011). Allelopathic effects of ten tree species on germination and growth of four traditional food crops in Ghana. Journal of Agricultural Technology, 7(3), 825-834.

[2] Alebachew, M., Amare, T., and Wendie, M. (2015). Investigation of the Effects of Eucalyptus camaldulensis on Performance of Neighbouring Crop Productivity in Western. Open Acess Library Journal. https://doi.org/10.4236/oalib.1100992

[3] Amare, A. (2015). Yield Response of Local Long Maturing Sorghum Varieties to Timing of Nitrogen Fertilizer Application in Eastern Amhara. Journal of Biology, Agriculture and Healthcare, 5(3), 184-190.

[4] Aminul, H., Zahir, M., Lal, B., Tanvir, B.,\&Irshad, U. (2019). Allelophatic effect of Eucalyptus camaldulensis L.on seed germination and seedling growth of Mungbean Vigna radiata(L,) Wilczek. Journal of Chemical Information and Modeling, 53(9), 1689-1699. https://doi.org/10.1017/CBO9781107415324.004

[5] Awadallah, B., \&, \& Eman,O. (2017). 4 Allelopathic Effect of Eucalyptus (Eucalyptus camaldulensis Dehnh) Leaf on Seed Germination and Seedling Growth of some Poaceous Crops. International Journal of Forest, Animal and Fisheries Research, 1(4), 34-40. https://doi.org/10.22161/ijfaf.1.4.4

[6] C S, H., H T, C., A.R, A., and Nd, R. H. (2000). Allelopathy research in agroforestry systems of South India. University OfAgricultural Sciences, Dharwad- 580 005, Kamataka, India, $\odot 2000$ Kluwer Academic Publishers., 209-227.

[7] Carolina, G., Lorena, Alvarez., Manuel, J.,\& Nuria, P. (2018). Eucalyptus globulus Leaves Incorporated as Green Manure for Weed Control in Maize. Weed Science, 6l(1), 154-161. https://doi.org/10.1614/ws-d-1200056.1

[8] Getachew, A. (2016). The impact of Eucalyptus planatation expansion on food security in Bambasi Woreda,Benishangul Gumuz regional state, Western Ethiopia.

[9] Hozayn, M., El Shahawy, TA., Abd El Monem, A., \& El Saady, A A.,\& Darwish, M. A. (2015). Allelopathic effect of Casuarina equisetifolia L. on wheat, associated weeds and nutrient content in the soil. African Journal of Agricultural Research, 10(14), 1675-1683. https://doi.org/10.5897/ajar2015.9482

[10] Kristina, A.Stuart, A., Jeff, R., Benjamin, E, Ragan, M., Giles, C., Steven, G., Daniel, P., andJohn, N. (2006). Invasive Plant Suppresses the Growth of Native Tree Seedlings by Disrupting Belowground Mutualisms. Plod Biology, 4(5). https:// doi.org/10.1371/ journal.pbio.0040140

[11] Kugedera, A.T., \& Kokerai, L. K. . (2019). Review: Agroforestry Species Have Negative Allelopathic Effect on Food and Fodder Crops. International Journal of Zamburt, 2(2), 78-83.

[12] M. G, Miah., D. P. Khasa., N. S. Safminl .,\&M.'A., R. (2010). Allelophatic effect Eucalyptus camaldulensis leaf extract on Germination and Growth of Mungbean. Ann.Bangladesh Agri., 4, 9-20.

[13] Marianne, K., Morten, S., and Beate, S. (2000). oEcological Effects of Allelopathic Plants-areview. In NERI Technical Report No. 315 (Issue 315). https://doi.org/citeulike-article-id:7530029

[14] Martial,D.,Nambinina,A., Felana,R., Rondro,H., Herizo, R., Calina,P., Damase,K., \&Heriniania,R. (2020). Allelopathic effects of Grevillea banksii $R$. BR. leaf extract and its rhizosphere soil on germination and intial growth of three Agricultural crops in Madagascar. July.

[15] Muhammad, A., Iqtidar, H., \&Ejaz, A. (2007). EFFECT OF AQUEOUS EXTRACT OF Eucalyptus camaldulensis L. ON GERMINATION AND GROWTH OF MAIZE (Zea mays L.). Pak. J. Weed Sci. Res, 13(4), 177-182.

[16] Raveendra, H., Chandrashekhar, S.,\&C, J. (2002). Effect of casuarina litter leachates on crops. Allelopathy Journal, October 2002, 141-146.

[17] Sazada, S., Shilpa, B., Shoukat, S., and Mukesh, K. (2009). Allelopathic Effect of Different Concentration of Water Extract of Prosopsis Juliflora Leaf on Seed Germination and Radicle Length of Wheat (Triticum aestivum Var-Lok-1). Journal of Scientific Research, 4(2), 81-84. 
[18] Sirawdink, F., Zerihun, K., Amsalu, N., Nardos , Z., \& Seifu, B. (2011). Allelopathic Effects of Eucalyptus camaldulensis Dehnh. On Germination and Growth of Tomato Allelopathic Effects of Eucalyptus camaldulensis Dehnh . on Germination and Growth of Tomato. American -Eurasian J.Agric.\&Envirom.Sci.11(5):600-608,2011, January.

[19] Talaat, A., Ahmed, A., \& Noura, H. (2019). Dataset of allelopathic effects of Casuarina equisetifolia-L leaf aquatic extract on seed germination and growth of selected plant crops. Data in Brief, 27(November), 104770. https://doi.org/10.1016/j.dib.2019.104770

[20] Tilashwork,C. (2009). The effect of Eucalyptus on crop productivity, and soil properties in the Koga watershed, Western Amhara Region,Ethiopia. May.

[21] Tim, M. (2007). A G R O F O R E S T RY PRINCIPLES.

[22] Yakubu, I., Aminu, S A.,\&Abdullahi, M. (2018). Influence of Allelochemicals Substances in Eucalyptus Species on Agricultural Crops: A Review. International Journal of Advances in Agricultural Science and Technology, 5(5), 25-32.

Citation: Andualem Ayalew \& Zebene Asfaw, "Allelophatic Effects of Gravellia Robusta, Eucalyptus Camaldulensis and Casuarina Equisetifolia on Germination and Root Length of Maize and Wheat" International Journal of Research Studies in Agricultural Sciences (IJRSAS), 2020; 6(11), pp. 15-20, https://doi.org/10.20431/2454-6224.0611004

Copyright: (C) 2020 Authors. This is an open-access article distributed under the terms of the Creative Commons Attribution License, which permits unrestricted use, distribution, and reproduction in any medium, provided the original author and source are credited. 